\title{
Salivary Gland Squamous Cell Carcinoma
}

National Cancer Institute

\section{Source}

National Cancer Institute. Salivary Gland Squamous Cell Carcinoma. NCI Thesaurus. Code C7991.

A squamous cell carcinoma arising from the salivary glands. The majority of patients are in their sixth through eight decades. It usually presents as a rapidly enlarg ing mass, which may be painful. It usually has an aggressive clinical course. 